\title{
Contrarian and Momentum Profits during Periods of High Trading Volume preceded by Stock Prices Shocks
}

\author{
Razvan Stefanescu \\ rstefanescu@ugal.ro \\ Ramona Dumitriu \\ rdumitriu@ugal.ro \\ Dunarea de Jos University of Galati, Romania
}

\begin{abstract}
This paper approaches the opportunities for contrarian and momentum profits during the periods of high trading volume preceded by stock prices shocks. We investigate these aspects for ten stocks from New York Stock Exchange. We found that more than three quarters of the periods of high trading volume were preceded by shocks which occurred less than six working days before. The values of the average excess returns for these periods suggest that opportunities for momentum profits prevailed over those for contrarian profits.
\end{abstract}

Keywords: Contrarian Strategy, Momentum Strategy, High Trading Volume, Shocks

JEL Code: G11, G12, G14

\section{Introduction}

The evolution of capital markets after major price increases (positive shocks) and declines (negative shocks) is largely approached in the financial literature. In the Behavioral Finance Theory framework there were revealed two main types of reaction to shocks that could be exploited in successful trading rules: overreaction and underreaction.

Overreaction Hypothesis (OH) developed by De Bondt and Thaler (1985) presumes that traders exaggerate the importance of the recent information, displaying too much optimism in the case of good news and too much pessimism in the case of bad news. The shocks caused by the arrival of such news could temporary move the stock prices far from their intrinsic values. However, after the shocks, the equilibrium tends to be reestablished and the positive shocks are followed by price declines and the negative shocks are followed by price increases (Shefrin \& Statman, 1985; Lo \& MacKinlay, 1990; Jegadeesh \& Titman, 1995). The overreaction phenomenon could be exploited by the contrarian strategies described by two trading rules: the selling after positive shocks and buying after negative shocks (De Bondt \& Thaler, 1985; Chan, 1988; Lakonishok et al., 1994; Antoniou et al., 2005). Underreaction Hypothesis (UH) proposed by Jegadeesh and Titman (1993) presumes that investors react slowly to recent information which is incorporated gradually in the stock prices. In that case the positive shocks are followed by price increases and the negative shocks are followed by price declines. Such reactions to shocks could be exploited by momentum strategies which apply two trading rules: the buying after positive shocks and selling after negative shocks (Chan et al., 1996; Daniel et al., 1998; Hong \& Stein, 1999; Jegadeesh \& Titman, 2001; Lesmond et al., 2004).

$\mathrm{OH}$ and UH contradict Efficient Market Hypothesis (EMH) proposed by Fama (1970) which denies the possibility to predict future evolutions of stock prices based on their past values. The empirical researches on the capital markets reactions to shocks led to results that favored $\mathrm{OH}$ and $\mathrm{UH}$ but also EMH. They also found that some particularities of stocks could significantly influence the reactions to shocks (Zarowin, 1989; Abarbanell \& Bernard, 1992; La Porta et al., 1997; Abarbanell \& Bushee, 1998; Rouwenhorst, 1998; Hong et al., 2000; Grinblatt \& Han, 2002; Chan, 2003; Lasfer et al., 2003; Zawadowski et al., 2006; Agyei-Ampomah, 2007; Galariotis et al., 2007; Spyrou et al., 2007; Chui et al., 2010; Novy-Marx, 2012; Savor, 2012; Caporale et al., 2014; Frisch et al., 2014; Govindaraj et al., 2014; Chaudhury \& Piccoli, 2015; He \& Li, 2015).

Sometimes, reactions to shocks are accompanied by substantial increase of the trading volume. Several studies found positive correlations between absolute values of returns and the volume 
of transactions (Crouch, 1970; Tauchen \& Pitts, 1983; Karpoff, 1986; Lakonishok \& Smidt, 1986; Karpoff, 1987; Campbell et al., 1992; Gallant et al., 1992; Chordia et al., 2001; Marsh \& Wagner, 2004). The trading volume was revealed as an important aspect of the reactions to shocks (Lee \& Swaminathan, 2000; Weber \& Rosenow, 2006).

The complexity of the reaction to shocks could be associated to the heterogeneous beliefs in financial markets (Zeeman, 1974; Beja \& Goldman, 1980; Haltiwanger \& Waldman, 1985; Brock \& Hommes, 1997; Brock \& Hommes, 1998). The Heterogeneous Agents Models (HAM) revealed the different behaviors of different categories of traders: fundamentalists, chartists, noise traders, contrarian investors, momentum investors etc. (DeLong et al., 1987; Schulmeister \& Goldberg, 1989; Shleifer \& Summers, 1990; Hommes, 2006; Bloomfield et al., 2009; He et al., 2009; Chiarella et al., 2011; Fischer, 2011; He \& Li, 2015).

In this paper we investigate the capital markets behaviors during periods of high trading volume preceded by stock prices shocks. We presume that, in such situations, the trading volume increase is caused by the traders who regard the stock prices shocks as opportunities for contrarian or momentum investment. We identify the shocks taking into consideration the opportunist traders perceptions on the stocks evolutions. We presume that these perceptions are made based on the differences between the stock returns and the return of an index which reflect the general evolution of the market (a kind of excess return) for a specific period of time, named the remembering period. However, as time goes, the impact of these excess returns is dissipating so we adjust their values to reflect the distance from the day that follows the remembering period.

We consider that a positive shock occurs when the excess return is significant larger than the maximum of the remembering period, while a negative shock occurs when the excess return is significant smaller than the minimum of the remembering period. We identify a day of high trading volume (DHTV) by comparing with the average of a past period. In a period of high trading volume (PHTD) we include such days but also days with low trading volume under condition that they are framed, at few days, between DHTVs. We associated shocks to a PHTD if they occur during them or precede it by few days.

We study the behavior of share prices for ten companies listed on New York Stock Exchange (NYSE). We investigate the returns from the PHTDs in order to reveal the opportunities of the contrarian and momentum profits.

The remainder of this paper is organized as follows: the second part describes the data and methodology employed to investigate the contrarian and momentum profits during the PHTDs preceded by shocks, the third part presents the empirical results and the fourth part concludes.

\section{Data and Methodology}

2.1. Data

In this investigation about the contrarian and momentum profits during periods of high trading volume we employ daily closing values and trading volume of ten stocks from NYSE: Alcoa Inc. (AAA), Bank of America Corporation (BAC), The Walt Disney Company (DIS), EMC Corporation (EMC), Freeport-McMoRan Inc. (FCX), The Gap, Inc. (GPS), Pfizer Inc. (PFE), United Health Group Incorporated (UNH),Wells Fargo \& Company (WFC) and Williams Companies, Inc. (WMB). We also use the daily closing values of a representative index of NYSE: the well known Standard \& Poor's 500 (S\&P 500). For all eleven items the data is provided by Yahoo! Finance. The sample of data covers the period January 2012 - March 2016.

\subsection{Computing the excess returns} $\left(\mathrm{R}_{\mathrm{i}, \mathrm{t}}\right)$ as:

We start by calculating, for each item (the ten stocks and the S\&P 500 index), the simple return

$$
R_{i, t}=\frac{P_{i, t}-P_{i, t-1}}{P_{i, t-1}} \times 100
$$

where $\mathrm{P}_{\mathrm{t}}$ and $\mathrm{P}_{\mathrm{t}-1}$ are the closing values of the item $\mathrm{i}$ on the days $\mathrm{t}$ and $\mathrm{t}-1$, respectively.

We also determine, for all ten stocks, the excess return $\left(\mathrm{Z}_{\mathrm{i}, \mathrm{t}}\right)$ using the Standard \& Poor's 500 index as a value of a reference asset:

$$
Z_{i, t}=R_{i, t}-R_{S \& P, t}
$$




\subsection{Identifying the shocks}

For the shocks identification we take into consideration a 30 days period of remembering that precedes a day $\mathrm{t}$ :

$$
R E M=[t-1 ; t-30]
$$

For all the days of a remembering period we adjust the excess returns to reflect their dissipating impact as time goes. We use the formula of a geometric progression with a less than one common ratio $(\rho)$ :

$$
\operatorname{adj}_{t}^{k}\left(Z_{i, t-k}\right)=Z_{t-k} \times \rho^{k}, k=1 \ldots 30
$$

where $\operatorname{adj}_{t}^{k}\left(Z_{i, t-k}\right)$ is the adjusted excess return for a day from remembering period that precedes with $\mathrm{k}$ days the day $\mathrm{t}$. In this paper we use a common ratio $\rho=0.9$.

For each period of remembering we calculate three values:

- the minimum value of the adjusted excess returns:

$$
m_{i, t}^{R E M}=\min \left(\operatorname{adj}_{t}^{k}\left(Z_{i, t-k}\right)\right), k=1 \ldots 30
$$

- the maximum value of the adjusted excess returns:

$$
M_{i, t}^{R E M}=\max \left(\operatorname{adj}_{t}^{k}\left(Z_{i, t-k}\right)\right), k=1 \ldots 30
$$

- the amplitude of the remembering period:

$$
A_{i, t}^{R E M}=M_{i, t}^{R E M}-m_{i, t}^{R E M}
$$

We identify the shocks by imposing the conditions:

- for positive shocks: $Z_{i, t}>M_{i, t}^{R E M}+0.2 \times A_{i, t}^{R E M}$

- for negative shocks: $Z_{i, t}<m_{i, t}^{R E M}-0.2 \times A_{i, t}^{R E M}$

\subsection{Characterizing the periods of high trading volume}

In this investigation we reveal some characteristics of PHTDs:

- number and length (in days) of PHTDs;

- the PHTDs preceded by positive or negative shocks;

- excess return for the first days of a PHTD;

- $\quad$ excess return for the whole PHTD.

We consider that a DHTV occurs when the trading volume (VT) exceeds, by 25 percents, the average of the precedent 30 days:

$$
\text { - } V T_{i, t}^{D H T V}>1.25 \times A V E R A G E\left(V T_{i, t-30} \ldots V T_{i, t-1}\right)
$$

A PHTD includes DHTVs identified but also some days with low trading volume, under the condition that low trading volume couldn't last more than five consecutive days.

We associate a shock to a PHTD only if it occurs during that period or precedes it by less than six working days. In case of multiple shocks that precede a PHTD we chose, for assigning to the positive or negative ones, the earliest shock.

The excess return for the first days of a PHTD could be calculated using the formula (2). For the whole period we compute the excess return $\left(Z_{i}^{P H T D}\right)$ as:

$$
Z_{i}^{\text {PHTD }}=\frac{P_{i, f}^{\text {PHTD }}-P_{i,-1}^{\text {PHTD }}}{P_{i,-1}^{\text {PHTD }}} \times 100-\frac{P_{S \& P, f}^{\text {PHTD }}-P_{S \& P,-1}^{\text {PHTD }}}{P_{S \& P,-1}^{P H T D}} \times 100
$$

where:

- $\quad P_{i, f}^{P H T D}$ is the closing value of the stock i at the end of PHTD;

- $\quad P_{i,-1}^{\text {PHTD }}$ is the closing value of the stock i for the day that precedes the PHTD; 
- $\quad P_{S \& P, f}^{P H T D}$ is the closing value of the S\&P 500 at the end of PHTD;

- $\quad P_{S \& P,-1}^{P H T D}$ is the closing value of the S\&P 500 for the day that precedes the PHTD. the $t$ test.

For these excess returns we calculate the averages and we test their significance by employing

\section{Empirical Results}

The Table 1 presents the shocks and the high trading volume periods identified for the ten stocks. In general, the number of negative shocks was larger than the number of positive shocks. The results indicate that, for each stock, more than a half of shocks, positive or negative, were associated to PHTD.

Table 1. Shocks of stock prices and high trading volume periods

\begin{tabular}{|c|c|c|c|c|}
\hline Stock & $\begin{array}{c}\text { Positive shocks } \\
\text { of stock prices }\end{array}$ & $\begin{array}{c}\text { Positive shocks associated to } \\
\text { high trading volume periods }\end{array}$ & $\begin{array}{c}\text { Negative shocks } \\
\text { of stock prices }\end{array}$ & $\begin{array}{c}\text { Negative shocks } \\
\text { associated to high } \\
\text { trading volume } \\
\text { periods }\end{array}$ \\
\hline AAA & 130 & 88 & 173 & 117 \\
\hline BAC & 112 & 73 & 187 & 96 \\
\hline DIS & 167 & 87 & 173 & 76 \\
\hline EMC & 153 & 91 & 142 & 90 \\
\hline FCX & 139 & 98 & 171 & 113 \\
\hline GPS & 149 & 100 & 161 & 118 \\
\hline PFE & 134 & 71 & 162 & 96 \\
\hline UNH & 137 & 81 & 153 & 93 \\
\hline WFC & 137 & 70 & 170 & 91 \\
\hline WMB & 125 & 76 & 197 & 118 \\
\hline
\end{tabular}

The Table 2 reports some characteristics of PHTDs. For each stock, more than three quarters of PHTDs were preceded by shocks. Excepting one stock, the number of PHTDs preceded by negative shocks and the days included in these periods is larger than in the case of PHTDs preceded by positive shocks.

Table 2. Characteristics of the high trading volume periods preceded by shocks

\begin{tabular}{|c|c|c|c|c|c|c|}
\hline \multirow[t]{2}{*}{ Stock } & \multirow{2}{*}{$\begin{array}{l}\text { High trading } \\
\text { volume } \\
\text { periods }\end{array}$} & \multirow{2}{*}{$\begin{array}{l}\text { High trading volume } \\
\text { periods preceded by } \\
\text { shocks }\end{array}$} & \multicolumn{2}{|c|}{$\begin{array}{l}\text { High trading volume } \\
\text { periods preceded by } \\
\text { positive shocks }\end{array}$} & \multicolumn{2}{|c|}{$\begin{array}{l}\text { High trading volume } \\
\text { periods preceded by } \\
\text { negative shocks }\end{array}$} \\
\hline & & & $\begin{array}{c}\text { Number of } \\
\text { periods }\end{array}$ & $\begin{array}{c}\text { Number of } \\
\text { days }\end{array}$ & $\begin{array}{l}\text { Number of } \\
\text { periods }\end{array}$ & $\begin{array}{l}\text { Number } \\
\text { of days }\end{array}$ \\
\hline AAA & 49 & 44 & 20 & 187 & 24 & 120 \\
\hline BAC & 57 & 53 & 22 & 78 & 31 & 131 \\
\hline DIS & 57 & 49 & 22 & 76 & 27 & 104 \\
\hline EMC & 59 & 52 & 28 & 109 & 24 & 137 \\
\hline FCX & 64 & 54 & 24 & 111 & 30 & 121 \\
\hline GPS & 59 & 51 & 23 & 115 & 28 & 148 \\
\hline $\begin{array}{l}\text { PFE } \\
\end{array}$ & 56 & 47 & 19 & 99 & 28 & 106 \\
\hline UNH & 48 & 43 & 14 & 98 & 29 & 125 \\
\hline WFC & 48 & 44 & 22 & 108 & 22 & 75 \\
\hline WMB & 50 & 48 & 18 & 85 & 30 & 200 \\
\hline
\end{tabular}

The average values of the excess returns for the PHTDs preceded by positive or negative shocks are presented in the Table 3. For the first day of PHTDs we found, in general, significant positive averages for the periods preceded by positive shocks and significant averages for those preceded by negative shocks. In the case of whole periods the results are mixed. For the PHTDs preceded by positive shocks we found significant positive averages for seven stocks and significant negative averages for three stocks. For the PHTDs preceded by negative shocks we found significant positive 
averages for one stock and significant negative averages for eight stocks. These results suggest that, for both positive and negative shocks, the opportunities for momentum profits dominate those for contrarian profits.

Table 3. Average excess returns for the high trading volume periods preceded by shocks

\begin{tabular}{|c|c|c|c|c|}
\hline \multirow[t]{2}{*}{ Stock } & \multicolumn{2}{|c|}{$\begin{array}{c}\text { Average excess return for the first day of the } \\
\text { period }\end{array}$} & \multicolumn{2}{|c|}{ Average excess return for the whole period } \\
\hline & $\begin{array}{l}\text { High trading volume } \\
\text { periods preceded by } \\
\text { positive shocks }\end{array}$ & $\begin{array}{l}\text { High trading volume } \\
\text { periods preceded by } \\
\text { negative shocks }\end{array}$ & $\begin{array}{l}\text { High trading volume } \\
\text { periods preceded by } \\
\text { positive shocks }\end{array}$ & $\begin{array}{l}\text { High trading volume } \\
\text { periods preceded by } \\
\text { negative shocks }\end{array}$ \\
\hline AAA & $2.1312^{* * *}$ & $-0.6492^{*}$ & $-1.2514^{* * *}$ & $-0.1703^{*}$ \\
\hline $\mathrm{BAC}$ & $2.1323^{* * *}$ & $-0.3722^{*}$ & $2.9010^{* * *}$ & $-0.4065^{* *}$ \\
\hline DIS & $0.2234^{*}$ & 0.0183 & $0.2864^{*}$ & $0.4325^{* *}$ \\
\hline EMC & -0.0506 & $-0.7194^{* *}$ & $-0.2797^{*}$ & $-0.3772^{*}$ \\
\hline FCX & $2.0080^{* * *}$ & $-1.9106^{* * *}$ & $2.3510^{* * *}$ & $-3.2372^{* * *}$ \\
\hline GPS & $1.6446^{* *}$ & $-0.8032^{* *}$ & $1.1064^{* *}$ & $-0.9757 * *$ \\
\hline PFE & $0.7839^{*}$ & $-0.5579^{*}$ & $1.3185^{* *}$ & $-0.5132^{* *}$ \\
\hline UNH & $0.8118^{*}$ & $-0.6309^{*}$ & $1.7292^{* *}$ & $-0.6942^{* *}$ \\
\hline WFC & $0.2031^{*}$ & $-0.2196^{*}$ & $-0.3752^{*}$ & -0.0796 \\
\hline WMB & $1.5182^{* *}$ & $-1.8848^{* * *}$ & $1.8851^{* *}$ & $-2.5239^{* * *}$ \\
\hline
\end{tabular}

Note: ${ }^{* * *}, * *, *$; mean significant at $0.01,0.05$, and 0.1 levels, respectively.

\section{Conclusions}

The relation between the shocks and PHTDs is characterized by complexity. In this investigation we found that more than a half of shocks were associated to PHTDs, while more than three quarters of the PHTDs were preceded by shocks. These aspects could be related to the opportunist traders' behaviors which are attracted by shocks. Perhaps most of them could be considered as chartists but, in some circumstances, fundamentalist traders who perceived the stock prices as too under or overvalued could also react to the shocks.

The averages of excess returns indicate that, for most of the stocks, the opportunities for momentum strategies prevail over those for contrarian strategies. However, in the case of long PHTDs (some of them could last for 4-5 weeks) an opportunist trader could pass from momentum to contrarian strategies and vice versa.

This investigation could be extended to other developed or emerging capital markets. It could also approach some aspect of the long PHTDs.

\section{References}

1. Abarbanell, J. S. \& Bernard, V. L. (1992). Tests of analysts' overreaction/underreaction to earnings information as an explanation for anomalous stock price behavior. The Journal of Finance, 47(3), 1181-1207.

2. Abarbanell, J. S. \& Bushee, B. J. (1998). Abnormal returns to a fundamental analysis strategy. The Accounting Review, 73(1), 19-45.

3. Agyei Ampomah, S. (2007). The Post Cost Profitability of Momentum Trading Strategies: Further Evidence from the UK. European Financial Management, 13(4), 776-802.

4. Antoniou, A., Galariotis, E. C. \& Spyrou, S. I. (2005). Contrarian profits and the overreaction hypothesis: The case of the Athens stock exchange. European Financial Management, 11(1), 71-98.

5. Baker, M., Ruback, R. S. \& Wurgler, J. (2004). Behavioral corporate finance: A survey. NBER Working Paper No. 10863.

6. Barberis, N., Shleifer, A. \& Vishny, R. (1998). A model of investor sentiment. Journal of Financial Economics, 49(3), 307-343.

7. Barberis, N. \& Thaler, R. (2003). A survey of behavioral finance. Handbook of the Economics of Finance, 1, 10531128.

8. Beja, A. \& Goldman, M. B. (1980). On the dynamic behavior of prices in disequilibrium. The Journal of Finance, 35(2), 235-248.

9. Bloomfield, R., O'Hara, M., \& Saar, G. (2009). How noise trading affects markets: An experimental analysis. Review of Financial Studies, 22(6), 2275-2302.

10. Blume, L., Easley, D. \& O'Hara, M. (1994). Market statistics and technical analysis: The role of volume. The Journal of Finance, 49(1), 153-181.

11. Brock, W. A. \& Hommes, C. H. (1997). A rational route to randomness. Econometrica: Journal of the Econometric Society, 1059-1095. 
12. Brock, W. A. \& Hommes, C. H. (1998). Heterogeneous beliefs and routes to chaos in a simple asset pricing model. Journal of Economic Dynamics and Control, 22(8), 1235-1274.

13. Campbell, J. Y. Grossman, S. J., \& Wang, J. (1992). Trading volume and serial correlation in stock returns. NBER Working Paper No. 4193.

14. Caporale, G. M., Gil-Alana, L. A., \& Plastun, A. (2014). Short-Term Price Overreaction: Identification, Testing, Exploitation. DIW Berlin Discussion Paper No. 1423

15. Chan, K. C. (1988). On the contrarian investment strategy. Journal of Business, 61, 147-163.

16. Chan, L. K. C., Jegadeesh, N., \& Lakonishok, J. (1996). Momentum strategies. The Journal of Finance, 51(5), 16811713.

17. Chan, W. S. (2003). Stock price reaction to news and no-news: Drift and reversal after headlines. Journal of Financial Economics, 70(2), 223-260.

18. Chen, J., Hong, H. \& Stein, J. C. (2001). Forecasting crashes: Trading volume, past returns, and conditional skewness in stock prices. Journal of Financial Economics, 61(3), 345-381.

19. Chaudhury, M. \& Piccoli, P. (2015). Stock Overreaction to Extreme Market Events. Proceedings of the European Financial Management Association 2015 Annual Meetings June 24-27, 2015, Amsterdam.

20. Chiarella, C., He, X. Z. \& Zheng, M. (2011). An analysis of the effect of noise in a heterogeneous agent financial market model. Journal of Economic Dynamics and Control, 35(1), 148-162.

21. Chordia, T., Subrahmanyam, A., \& Anshuman, V. R. (2001). Trading activity and expected stock returns. Journal of Financial Economics, 59(1), 3-32.

22. Chui, A. C., Titman, S. \& Wei, K. J. (2010). Individualism and momentum around the world. The Journal of Finance, 65(1), 361-392.

23. Crouch, R. L. (1970). The volume of transactions and price changes on the New York Stock Exchange. Financial Analysts Journal, 26(4), 104-109.

24. Daniel, K., Hirshleifer, D. \& Subrahmanyam, A. (1998). Investor psychology and security market under and overreactions. The Journal of Finance, 53(6), 1839-1885.

25. De Bondt, W. \& Thaler, R. H. (1985). Does the Stock Market Overreact?. The Journal of Finance, 40(3), 793-805.

26. DeLong, J. B., Shleifer, A., Summers, L. H. \& Waldmann, R. J. (1987). The economic consequences of noise traders. NBER Working Paper No. 2395.

27. Dumitriu, R., Stefanescu, R. \& Nistor, C. (2011). Changes in the dynamic relation between the prices and the trading volume from the Bucharest stock exchange. Proceedings of the 18th International Economic Conference - IECS 2011, „Crises After The Crisis. Inquiries From a National, European and Global Perspective”, Universitatea Lucian Blaga, Sibiu.

28. Dumitriu, R. \& Stefanescu, R. (2013). Reactions to Shocks of the Romanian Companies Stock Prices. Proceedings of the International Conference of Scientific Paper AFASES 2013, "Henri Coanda" Air Force Academy, Brasov.

29. Fama E. F. (1970). Efficient Capital Markets: A Review of Theory and Empirical Work, Journal of Finance, Vol. 25, 383-417.

30. Fama E. F. (1998). Market Efficiency, Long-Term Returns and Behavioural Finance, Journal of Financial Economics, 49, 283-306.

31. Fama E. F. (1991). Efficient capital markets: II, Journal of Finance, 46, 1575-1617.

32. Fischer, T. (2011). News reaction in financial markets within a behavioral finance model with heterogeneous agents. Algorithmic Finance, 1(2), 123-139.

33. Frisch, T., Kolaric, S. \& Schiereck, D. (2014). Returns on large stock price declines and increases in the South African stock market: a note on market efficiency. The International Business \& Economics Research Journal, 13(3), 581-592.

34. Gallant, A. R., Rossi, P. E. \& Tauchen, G. (1992). Stock prices and volume. The Review of Financial Studies, 5(2), 199-242.

35. Galariotis, E. C., Holmes, P. \& Ma, X. S. (2007). Contrarian and momentum profitability revisited: Evidence from the London Stock Exchange 1964-2005. Journal of Multinational Financial Management, 17(5), 432-447.

36. Govindaraj, S., Livnat, J., Savor, P. G. \& Zhao, C. (2014). Large Price Changes and Subsequent Returns. Journal of Investment Management, 12(3), 31-58.

37. Granger, C. W. \& Morgenstern, O. (1962). Spectral Analysis of New York Stock Market Prices. Econometric Research Program, Research Memorandum No. 45.

38. Grinblatt, M. \& Han, B. (2002). The disposition effect and momentum. NBER Working Paper 8734.

39. Grossman, S. J. \& Stiglitz, J. E. (1980). On the impossibility of informationally efficient markets. The American Economic Review, 70(3), 393-408.

40. Haltiwanger, J. \& Waldman, M. (1985). Rational expectations and the limits of rationality: An analysis of heterogeneity. The American Economic Review, 75(3), 326-340.

41. He, X. Z., Li, K., Wei, J. \& Zheng, M. (2009). Market stability switches in a continuous-time financial market with heterogeneous beliefs. Economic Modelling, 26(6), 1432-1442.

42. He, X. Z. \& Li, K. (2015). Profitability of time series momentum. Journal of Banking \& Finance, 53, 140-157.

43. Hirshleifer, D. (2001). Investor psychology and asset pricing. The Journal of Finance, 56(4), 1533-1597.

44. Hommes, C. H. (2006). Heterogeneous agent models in economics and finance. Handbook of computational economics, 2, 1109-1186.

45. Hong, H. \& Stein, J. C. (1999). A unified theory of underreaction, momentum trading, and overreaction in asset markets. The Journal of Finance, 54(6), 2143-2184. 
46. Hong, H., Lim, T. \& Stein, J. C. (2000). Bad news travels slowly: Size, analyst coverage, and the profitability of momentum strategies. The Journal of Finance, 55(1), 265-295.

47. Jegadeesh, N. \& Titman, S. (1993). Returns to buying winners and selling losers: Implications for stock market efficiency. The Journal of Finance, 48(1), 65-91.

48. Jegadeesh, N. \& Titman, S. (1995). Overreaction, delayed reaction, and contrarian profits. Review of Financial Studies, 8(4), 973-993.

49. Jegadeesh, N. \& Titman, S. (2001). Profitability of momentum strategies: An evaluation of alternative explanations. The Journal of Finance, 56(2), 699-720.

50. Karpoff, J. M. (1986). A theory of trading volume. The Journal of Finance, 41(5), 1069-1087.

51. Karpoff, J. M. (1987). The relation between price changes and trading volume: A survey. Journal of Financial and Quantitative Analysis, 22(01), 109-126.

52. La Porta, R., Lakonishok, J., Shleifer, A. \& Vishny, R. (1997). Good news for value stocks: Further evidence on market efficiency. The Journal of Finance, 52(2), 859-874.

53. Lakonishok, J. \& Smidt, S. (1986). Volume for winners and losers: Taxation and other motives for stock trading. The Journal of Finance, 41(4), 951-974.

54. Lakonishok, J., Shleifer, A. \& Vishny, R. W. (1994). Contrarian investment, extrapolation, and risk. The Journal of Finance, 49(5), 1541-1578.

55. Lasfer, M. A., Melnik, A. \& Thomas, D. (2003). Stock Price Reaction in Stressful Circumstances: An International Comparison. Journal of Financial Economics, 40.

56. LeBaron, B. (2006). Agent-based computational finance. Handbook of computational economics, 2, 1187-1233.

57. Lee, C. \& Swaminathan, B. (2000). Price momentum and trading volume. The Journal of Finance, 55(5), 20172069.

58. Lesmond, D. A., Schill, M. J. \& Zhou, C. (2004). The illusory nature of momentum profits. Journal of Financial Economics, 71(2), 349-380.

59. Lo, A. W. \& MacKinlay, A. C. (1990). When are contrarian profits due to stock market overreaction?. Review of Financial Studies, 3(2), 175-205.

60. Mandelbrot, B. (1963). The Variation of Certain Speculative Prices. The Journal of Business, 36(4), 394-419.

61. Marsh, T. A. \& Wagner, N. (2004). Return-volume dependence and extremes in international equity markets. EFA 2003 Annual Conference Paper No. 284; Research Program in Finance RPF No. 293.

62. Miller, E. M. (1977). Risk, uncertainty, and divergence of opinion. The Journal of Finance, 32(4), 1151-1168.

63. Novy-Marx, R. (2012). Is momentum really momentum?. Journal of Financial Economics, 103(3), 429-453.

64. Osborne, M. M. (1959). Brownian motion in the stock market. Operations Research, 7(2), 145-173.

65. Rouwenhorst, K. G. (1998). International momentum strategies. The Journal of Finance, 53(1), 267-284.

66. Savor, P. G. (2012). Stock returns after major price shocks: The impact of information. Journal of Financial Economics, 106(3), 635-659.

67. Schulmeister, S. \& Goldberg, M. D. (1989). Noise trading and the efficiency of financial markets. The American financial system: Between euphoria and crisis, Quaderni della Fondazione Adriano Olivetti, Berlin, 117-153.

68. Shefrin, H. \& Statman, M. (1985). The disposition to sell winners too early and ride losers too long: Theory and evidence. The Journal of Finance, 40(3), 777-790.

69. Shiller, R. J. (2003). From efficient markets theory to behavioral finance. The Journal of Economic Perspectives, 17(1), 83-104.

70. Shleifer, A. \& Summers, L. H. (1990). The noise trader approach to finance. The Journal of Economic Perspectives, 4(2), 19-33.

71. Spyrou, S., Kassimatis, K. \& Galariotis, E. (2007). Short-term overreaction, underreaction and efficient reaction: evidence from the London Stock Exchange. Applied Financial Economics, 17(3), 221-235.

72. Stefanescu, R., Dumitriu, R. \& Nistor, C. (2012). Short term momentum and contrarian profits on the Bucharest Stock Exchange before and during the global crisis. Analele Universității „Eftimie Murgu” Reșiţa, 19(2), 344-353.

73. Tauchen, G. E. \& Pitts, M. (1983). The price variability-volume relationship on speculative markets. Econometrica: Journal of the Econometric Society, 485-505.

74. Tversky, A. \& Kahneman, D. (1974). Judgment under uncertainty: Heuristics and biases. Science, New Series, 185(4157), 1124-1131.

75. Weber, P. \& Rosenow, B. (2006). Large stock price changes: volume or liquidity?. Quantitative Finance, 6(1), 7-14.

76. Zarowin, P. (1989). Does the stock market overreact to corporate earnings information?. The Journal of Finance, 44(5), 1385-1399.

77. Zawadowski, Á. G., Andor, G., \& Kertész, J. (2006). Short-term market reaction after extreme price changes of liquid stocks. Quantitative Finance, 6(4), 283-295.

78. Zeeman, E. C. (1974). On the unstable behaviour of stock exchanges. Journal of Mathematical Economics, 1(1), $39-49$. 